\title{
MARX CRÍTICO DE HEGEL: PARA ALÉM DA DEMOCRACIA COMO CONSCIÊNCIA INFANTIL DA RAZÃO
}

\author{
Júlia Lemos Vieira ${ }^{1}$
}

\begin{abstract}
Resumo:
Hegel buscou em seus Princípios da Filosofia do Direito uma resolução para a antinomia moderna entre Estado e sociedade civil esboçada numa Filosofia da História particular, a qual desenvolvera uma irreconciliável oposição entre liberdade real e democracia. Tais Princípios logo chamarão a atenção do Marx republicano no momento em que este tensionava-se com a dialética hegeliana e os movimentos comunistas que insurgiam na França. Para Hegel, a razão mais filosófica teria ultrapassado o momento do Estado democrático porque este fora a razão em sua consciência infantil obrigando-a a realizar-se absolutamente consciente apenas na unidade madura de uma Monarquia Constitucional. Para Marx, entretanto, a irrevogabilidade da perdição da inocência de Hegel é antes a admissão de uma irrevogabilidade do domínio da propriedade privada, a qual fundamentara a ilusão de uma solução formal como solução real. A Crítica à Filosofia do Direito de Hegel de Marx indicará que apenas a dissolução do interesse público como uma forma em si traria a liberdade humana efetiva e que o aprofundamento da democracia demandaria justamente tal dissolução ao desenvolver a dissolução da propriedade privada em seu caráter de interesse público.
\end{abstract}

Palavras-chave: História, Direito, Razão, Estado, Propriedade privada.

\begin{abstract}
:
Hegel sought in his Principles of Philosophy of Right a resolution to the modern antinomy between State and civil society outlined in a particular Philosophy of History, which had developed an irreconcilable opposition between real freedom and democracy. These principles will catch soon the attention of the Republican Marx at the time he was tensioned with the Hegelian dialectic and communist movements that emerged in France. According to Hegel, the most philosophical reason would have exceeded the time of the democratic State, because this was the reason in its children's consciousness forcing it to make itself absolutely conscious only in the mature unit of a Constitutional Monarchy. For Marx, however, Hegel's irrevocability of innocence destruction is before the admission of an irrevocability of the private property domain, which has substantiated the illusion of a formal solution as a real solution. The work Critique of Hegel's Philosophy of Right written by Marx indicates that only the public interest dissolution, as a way in itself, would bring the effective human freedom and that the strengthening of democracy would demand exactly such dissolution to develop the dissolution of private property in its character of public interest.
\end{abstract}

Keywords: History, Law, Reason, State, Private property.

\footnotetext{
${ }^{1}$ Doutoranda em Filosofia Política na Universidade de São Paulo (USP). Professora Convidada no Departamento de Publicidade e Propaganda na Pontifícia Universidade Católica de Goiás.
} 
Hegel buscou em seus Princípios da Filosofia do Direito $^{2}$ uma resolução para a antinomia moderna entre Estado e sociedade civil esboçada numa Filosofia da História ${ }^{3}$ particular, a qual indicara que o processo de realização da razão-consciente, condição para a liberdade humana, é o desenvolvimento filosófico da razão através do Estado. A razão, enquanto razão-princípio da natureza e dos homens, não se sabe livre de pronto. Realizar a razão-filosófica é o único modo de realizar a liberdade dos homens e a razãofilosófica só se autodetermina através da história concreta dos mesmos. É apenas enquanto razão-humana - espírito - que ela passa a saber-se livre, de modo que o processo para esse saber-se livre é a história. Neste sentido, ele afirma que a razão não seria dotada de inteligência a reger o mundo de modo consciente desde o início, tal como considerara a tradição religiosa:

\begin{abstract}
Essa manifestação do pensamento de que a razão governa o mundo está ligada a uma outra aplicação, que conhecemos na forma de verdade religiosa (...) Já esclareci que não tencionava recorrer à vossa fé no princípio da razão (...) $\mathrm{A}$ Providência divina é a sabedoria que, com um poder infinito, concretiza seus objetivos, isto é, o objetivo absoluto e racional do mundo: a razão é o pensar livre e determinante de si mesmo (HEGEL, 1999, p. 19).
\end{abstract}

Hegel tentara afirmar sua razão num idealismo objetivo desenvolvendo-a como uma espécie de Providência não consciente que determina a si mesma através do desenvolvimento da consciência dos homens. Para ele o desenvolvimento do conhecimento pelos homens é o desenvolvimento do conhecimento do espírito: a consciência humana é a própria consciência da Providência. Hegel indica que só nos homens a Razão se conhece porque na natureza e nos demais animais a Razão não é espírito tal como o é nos homens. Mas o desenvolvimento deste conhecimento é também propriamente o desenvolvimento de uma divisão da Razão, na medida em que através do conhecimento o homem tem o infortúnio de perceber-se separado da natureza e, neste sentido, sofre a perda do primeiro momento de unidade feliz com a natureza. Para Hegel, esse processo de conhecimento como processo de divisão da Razão em homem (espírito, ser para si) e natureza (não espírito) é representado no mito do pecado original:

Encontra-se a representação mítica desse espírito logo no início dos livros judeus, na narrativa do pecado original. Conta-se que o homem, criado à

\footnotetext{
${ }^{2}$ Trata-se do Grundlinien der Philosophie des Rechts oder Naturrecht und Sattswissenchaft im Grudrisse, publicado em 1821, ao qual nos recorremos através da versão HEGEL, G. W. F. Princípios da Filosofia do Direito. São Paulo: Martins Fontes, 2003.

${ }^{3}$ Trata-se pensamento de Hegel sobre a História exposto na obra póstuma intitulada Introdução à Filosofia da História, composto a partir de aulas ministradas pelo filósofo registradas em anotações suas e de alunos, ao qual nos recorremos através da versão HEGEL, G. W. F. Filosofia da História. Tradução de Maria Rodrigues e Hans Harden. 2a Edição. Brasília: Editora da Universidade de Brasília, 1999.
}

\begin{tabular}{|l|l|l|l|l|}
\hline Qenista Dialectus & Ano 2 & n. 3 & Julho-Dezembro 2013 & p. 84-102 \\
\hline
\end{tabular}


imagem e semelhança de Deus, perdeu o seu contentamento absoluto ao comer da árvore do conhecimento do bem e do mal. O pecado aqui reside no conhecimento: ele é pecaminoso, e por sua causa o homem perdeu a felicidade natural. É bem verdade que o mal reside na consciência, pois os animais não são bons nem maus, da mesma forma que o homem natural. (...) O paraíso é um jardim onde só os animais podem permanecer, não os homens (...) Só o homem é espírito, ou seja, para si mesmo. Esse ser para si, essa consciência é, todavia, a divisão do espírito universal divino. (...) O pecado original é, por isso, o eterno mito do homem, pelo qual ele se torna humano.

Diferentemente dos outros animais, o homem é a consciência da razão, ou seja, é espírito. Neste sentido, é inevitável que o homem se torne mais humano passando por seu estranhamento em relação à natureza: nele o espírito universal torna-se ser para si, ser consciente de si. Deste modo, o processo de conhecimento dado na própria natureza do homem é sempre também um processo de perda da unidade paradisíaca com a natureza.

Mas essa divisão não é eterna. Há o momento de redenção, de reestabelecimento da unidade ${ }^{4}$, ainda que não nos mesmos termos da unidade primeira. No final do processo, ainda que não haja mais uma unidade ingênua e feliz, há uma unidade madura, que conhece o negativo, mas o abraça como parte de si. A história do desenvolvimento da razão filosófica pode ser contada pela história do desenvolvimento do Estado. Em termos gerais, Hegel conta essa história nos o seguinte modo:

Os orientais ainda não sabem que o espírito, ou o homem como tal, é livre em
si mesmo; e porque não o sabem, eles não o são. (...) só entre os gregos é que
surgiu a consciência da liberdade, e por isso eles foram livres; mas eles, bem
como os romanos, sabiam somente que alguns eram livres (...) no cristianismo
tomaram consciência de que o homem é livre como homem, (...) [mas a
liberdade] não reinou logo a seguir, e tampouco os governos e as constituições
foram organizados de maneira racional ou sequer baseados no princípio da
liberdade (HEGEL, 1999, p. 24).

O momento do cristianismo é afirmado por Hegel como o momento do humanismo consciente enquanto conceito. Na sequência, indica que com a Reforma de Lutero "entramos assim no espírito consciente de sua liberdade (...) Este é o conteúdo essencial da Reforma: o homem está determinado por si mesmo a ser livre” (HEGEL, 1999, p. 343), que no Iluminismo "o espírito reconhece que a natureza, o mundo, precisa ter uma razão na existência" (Ibidem) e que é apenas a Revolução Francesa que constitui o Estado livre constitui a razão na existência. Entretanto, essa existência inicial ainda é uma forma imperfeita e por fim, a monarquia constitucional do Estado

\footnotetext{
${ }^{4}$ Nas palavras de ARANTES (2005, p. 9), para Hegel, "Se o homem não conseguisse reunir as partes separadas de seu mundo, e trazer a natureza e a sociedade para dentro do campo de sua razão, estaria para sempre condenado à frustração. O papel da filosofia, nesse período de desintegração geral, deveria ser o de evidenciar o princípio que restauraria a perdida unidade e totalidade".
}

\begin{tabular}{|c|c|c|c|c|}
\hline Qevista Qialectus & Ano 2 & n. 3 & Julho-Dezembro 2013 & p. $84-102$ \\
\hline
\end{tabular}


Germânico é que seria a realização mais perfeita da razão livre, do verdadeiro espírito consciente. O desenvolvimento da razão livre culminaria assim na absoluta realidade de suas potencialidades com o Estado prussiano de então, no período conhecido como Restauração (após Napoleão perder o domínio da Alemanha).

Com essa filosofia da história, Hegel considerou que a República Democrática fora uma forma estatal própria apenas a um momento anterior da razão; momento de anteposição dos homens em relação ao mundo, a uma realidade de continuidade entre o particular e o público, momento de consciência infantil da razão. E este momento teria desaparecido para sempre após o desenvolvimento do conhecimento na sociedade grega - levando à própria decadência desta. Hegel (1999, p. 343) retomou Montesquieu em seu argumento: “A virtude é a base democracia, diz Montesquieu. Essa citação é tão importante quanto verdadeira no tocante à representação que normalmente é feita da democracia”. A virtude como sobreposição do bem comum só pode reinar no modo imediato, na consciência feliz da razão. Daí o absurdo de se pretender uma democracia na modernidade.

A vitalidade concreta nos gregos é a moralidade objetiva, a vida pela religião, pelo Estado, sem muitas reflexões, sem determinações universais que, ao mesmo tempo, se distanciem da deformação concreta e que precisem colocarse perante ela. A lei existe e o espírito está nela. Todavia, logo que o pensamento surge, ele analisa as constituições: indica o que seria o melhor e exige que aquilo que ele reconheceu como o melhor substitua o existente (HEGEL, 1999, p. 227).

O problema com a tentativa de democracia na modernidade estaria justamente na impossibilidade do reino da virtude como abnegação, sacrifício. E tal seria inevitavelmente o caso da vida moderna. Nesta, não é a liberdade objetiva e sim a liberdade subjetiva que fundamenta a vida pública. No caso dos gregos, o objetivo de vida pessoal dos era de fato a pátria, a comunidade, o Estado não era uma abstração (separação). A virtude imediata, base para a democracia grega, já não seria possível num contexto em que já existe uma razão livre desenvolvida como subjetividade livre. Já que "o paraíso é um jardim onde só os animais podem permanecer, não os homens" (Ibidem), não era mais possível aos modernos a democracia: este era um Estado próprio da continuidade imediata homens-mundo perdida para sempre com o desenvolvimento da consciência especulativa, a unidade da liberdade subjetiva com a liberdade objetiva na modernidade só pode ser formal. Foi o desenvolvimento da liberdade subjetiva que levou ao declínio da democracia na Grécia e na vida moderna é a liberdade subjetiva que reina na vida moderna: "Justamente a liberdade subjetiva, que determina o princípio

\begin{tabular}{|l|l|l|l|l|}
\hline Qevista Dialectus & Ano 2 & n. 3 & Julho-Dezembro 2013 & p. 84-102 \\
\hline
\end{tabular}


e a forma característica da liberdade em nosso mundo - que é o fundamento do nosso Estado e da nossa vida religiosa - significou para a Grécia a ruína” (HEGEL, 1999, p. 213).

Após o desenvolvimento da razão livre, portanto, o indivíduo nunca mais terá no Estado uma identidade completa, o Estado não poderá ser mais que uma unidade meramente formal entre interesse individual e coletivo. Perante essa constatação, o Estado maduro próprio da razão madura seria a unidade como desenvolvimento meramente formal - e não o que pretende um unidade concreta, tal como a Democracia. A razão moderna mais plenamente consciente como forma voltada a si: só se realiza plenamente numa Monarquia Constitucional, o Estado absoluto em si.

Hegel não concordou com Adam Smith (A Riqueza das Nações) no que tange a uma completa espontaneidade moral no sistema de competição livre. Este só desenvolveria as paixões individuais para o bem comum num primeiro momento, mas num segundo haveria uma espécie de falência da mão-invisível não realizada na forma de Estado. De modo crítico ao liberalismo de Smith, considerou que a transposição das paixões individuais ao bem comum exigia mediações que limitassem a completa liberdade dos interesses privados. Opôs-se à democracia no bojo de sua oposição ao capitalismo desenfreado. Era preciso um Estado que repusesse a racionalidade pública que a competitividade comercial destrói sem, ao mesmo tempo, retroceder no progresso material. Como bem expõe Desai (2003, p. 53),

\footnotetext{
Hegel estava à frente de seu tempo. Sua oposição ao individualismo e à democracia representativa se baseava no vazio da liberdade individual abstrata. $\mathrm{Na}$ sua opinião o povo precisa ser mais do que um conjunto de indivíduos livres e autônomos (...) O Estado precisava defender a sociedade civil - a economia de mercado - contra ela mesma, atendendo ao maior interesse.
}

O Estado racional em Hegel, portanto, seria aquele que atuaria de modo a prevenir a sobreposição do interesse individual na sociedade. A realidade moderna expressava uma segregação do espírito desenvolvida que não permitia mais a democracia - unidade feliz - mas exigia a monarquia constitucional - unidade madura no sentido de que não cabia mais o retrocesso em relação ao desenvolvimento do individualismo. Ao indicar que a possibilidade de democracia ficou no momento de consciência infantil da Razão e desapareceu pra sempre, Hegel simultaneamente indicou a impossibilidade de revogação do sistema de propriedade privada numa república democrática:

A ideia que a consciência forma habitualmente sobre a necessidade ou a utilidade da colaboração dos corpos legislativos é provavelmente a de que são 
os representantes do povo, ou antes, o próprio povo, quem deve compreender melhor do que ninguém o que de fato interessa ao seu próprio bem estar e a de que é ele quem tem maior vontade de realizar esse bem-estar. No que diz respeito ao primeiro ponto, o problema consistirá antes no fato de o povo quando esta palavra designa uma determinada parte do Estado - constituir precisamente a parte que não sabe o que quer. Saber o que se quer, ou melhor, o que quer a vontade em si e para si, a razão, é o fruto de um conhecimento profundo e de uma inteligência que não são características do povo. (...) As assembleias, que surgiram dos indivíduos, do ponto de vista privado e dos interesses particulares - se inclinam a ter uma atividade a favor de si mesmas e a expensas do interesse geral (HEGEL, 1821, apud MARX, 1843, p. 97).

Perdida a unidade espontânea entre interesse particular e interesse geral, a democracia tenderia a favorecer apenas os interesses particulares. Em Hegel o interesse geral é a verdadeira racionalidade pública, mas, ao mesmo tempo, a única racionalidade que existe na forma não abstrata é sempre racionalidade particular. Deste modo, o interesse geral só pode ser impor de modo formal e através da soberania natural de um indivíduo. Daí a necessidade de diversas mediações nas quais os interesses particulares diversos se subsumissem ao interesse do monarca como interesse geral.

Família, religião, classes e poderes políticos seriam momentos necessários no processo de submissão dos diversos indivíduos ao monarca. Num primeiro momento a razão, inconscientemente, se expressa em natureza e decomposta nos seres humanos individualizados. No seu processo de conscientização, o isolamento individual é negado pela família, depois reestabelecido na sociedade civil (que nega a família) e depois é negado novamente pela divisão desta em classes. As classes seriam um momento de mediação essencial para que os interesses particulares não se voltassem contra o Estado, o interesse geral, mas se subsumissem nele:

Consideradas como órgão mediador, as classes estão colocadas entre o governo em geral por um lado e o povo decomposto em esferas particulares e em indivíduos. O seu papel impõe-lhes o sentido e a mentalidade do Estado e do governo, assim como o sentido e a mentalidade dos interesses das esferas particulares e dos indivíduos. Simultaneamente, esta posição tem o significado de uma mediação comum ao poder governativo orgânico, a fim de que o poder soberano não pareça isolado como um extremo, e, portanto, uma simples autoridade soberana e um arbítrio, a fim de que os interesses particulares das comunidades, corporações e indivíduos não estejam isolados nem, principalmente, os indivíduos cheguem a representar uma multidão e uma massa, antes se mantendo como expressão inorgânica do pensamento e da vontade e como simples poder compacto frente ao Estado orgânico (HEGEL, 1821, apud MARX, 1843, p. 103).

As classes seriam para Hegel mediações necessárias para a submissão dos interesses individuais ao interesse geral. Mais especificamente, o poder governativo

\begin{tabular}{|l|l|l|l|l|}
\hline Qevista Dialectus & Ano 2 & n. 3 & Julho-Dezembro 2013 & p. 84-102 \\
\hline
\end{tabular}


seria composto pela classe média ${ }^{5}$, a qual exerceria assim uma representação meramente burocrática daqueles que a elegeram, já que na prática executaria o interesse geral do Estado; e o poder legislativo seria composto pela classe do morgadio, vinculada à propriedade agrária inalienável e transmissível apenas aos primogênitos de sangue. Hegel considerava que esta classe específica tinha o mérito de ter seu interesse particular (classista) similar ao interesse geral, ou seja, por ser um particular especial que expressa o interesse geral em si. ${ }^{6}$

O interesse geral deveria ser cumprido pela sociedade civil, portanto, através de classes específicas com poderes de estado específicos, não sendo propriamente derivado da sociedade civil numa eleição democrática. A soberania do interesse geral estaria na única possibilidade de soberania na maturidade do espírito: soberania individual. $\mathrm{O}$ monarca seria a soberania do interesse geral porque na racionalidade desenvolvida e não ingênua só no modo individual existe de modo soberano. A razão consciente sabe-se soberana apenas como soberania particular, individual. É assim que a soberania do Estado não estaria na sua determinação popular e sim na sua indeterminação popular. As classes com poderes no Estado, classe média e classe dos morgadios, não seriam determinantes na razão do Estado, já que esta derivaria sobretudo do elemento constituinte, elemento indeterminado fundante do Estado e que o mantém soberano.

Assim, só a Monarquia Constitucional solucionaria uma questão nodal da antinomia moderna expressa pela Revolução Francesa: como poderia ser soberana uma constituição revogável? Como poderia o poder legislativo ter poder de alteração da constituição sem retirar a soberania da constituição? Para Hegel, apenas a constituição constituinte era uma resolução cabível, racional. Trata-se de uma constituição que só parcialmente pode ser determinada pelo poder legislativo e que mantém um pressuposto intocável e irrevogável. “Ao poder legislativo dizem respeito as leis enquanto tais que

\footnotetext{
${ }^{5}$ Única inteligente e culta o suficiente para ser aprovada nos exames para o posto do executivo. Os funcionários seriam escolhidos como representantes pelos cidadãos, mas deveriam "provar que são idôneos para as tarefas do Estado, ou seja, devem submeter-se a exames (...) Os membros do governo e os funcionários do Estado constituem a principal parte da classe média, onde se encontra a inteligência culta e a consciência jurídica da massa de um povo. Para evitar que essa classe média adote a situação isolada de uma aristocracia (...) existem as supremas instituições da soberania e os direitos das corporações de base" (HEGEL, 1821, apud MARX, 1843, p. 68).

6 "Uma das classes da sociedade civil encerra o princípio que tende a eleva-la a essa relação política, ou seja, a constituir-se como classe da moralidade natural que agem por base a vida familiar e, considerando a subsistência, a propriedade agrária; e que portanto, considerando a sua particularidade, tem em comum com o elemento soberano um querer baseado em si mesmo assim como a determinação natural contida no elemento soberano" (HEGEL, 1821, apud MARX, 1843, p. 144) e "A razão do morgadio consiste no fato de o Estado não poder contar com uma simples possibilidade de sentimentos, mas com sua necessidade (...) quem possui uma fortuna independente não é limitado por condições externas e pode adotar uma atitude livre, trabalhando para o bem do Estado" (HEGEL apud MARX 1843, p, 149).
}

\begin{tabular}{|c|c|c|c|c|}
\hline Qenista Qialectus & Ano 2 & n. 3 & Julho-Dezembro 2013 & p. $84-102$ \\
\hline
\end{tabular}


necessitam de um desenvolvimento complementar (...) Este poder constitui uma parte da constituição que lhe é pressuposta e situa-se em e para si fora da determinação direta desta constituição" (HEGEL, 1821, apud MARX, 1843, p. 84). A parte da constituição não determinada diretamente pela constituição é a parte que Hegel afirma como "decisão da vontade e no qual os diversos poderes são agrupados numa unidade individual que constitui a cúpula e o fundamento da totalidade" (HEGEL, 1821, apud MARX, 1843, p. 29). Trata-se da Ideia objetivada no monarca: os poderes são unos numa unidade individual.

Para Hegel, a constituição constituinte é tanto uma determinação quanto uma indeterminação e a indeterminação é um único indivíduo. É na pessoa do monarca que o elemento constituinte, racionalidade que se autoconstitui, surge efetivamente. Deste modo, a sujeição de todos os poderes ao interesse soberano do monarca é uma sujeição ao verdadeiro interesse geral em si, soberano porque indeterminado: "Este ato absoluto de autodeterminação constitui o princípio característico do poder soberano enquanto tal (...) a soberania existe apenas como autodeterminação abstrata e, portanto, privada de fundamento" (HEGEL, 1821, apud MARX, 1843, p. 29).

Assim, a razão soberana é apenas a razão que mantém um elemento como autodeterminação, nunca a razão completamente determinada. E a razão só se mantém autodeterminação quando é individual: “A personalidade e a subjetividade só tem como elemento empírico que se refere a si mesmo - a verdade, a sua verdade próxima e imediata, enquanto pessoa, enquanto sujeito existente para si. E o que existe para si é completa e simplesmente individual” (HEGEL, 1821, apud MARX, 1843, p. 41). O interesse geral desenvolvido soberano num Estado racional é o desenvolvido num Estado personificado: “a personalidade do Estado só se torna real como pessoa, e no monarca" (Ibidem). A dissolução dos extremos opostos retomava a Idade Média em alguma medida: a divisão em classes impediria o conflito aberto entre o povo e o Estado que a constituição representativa, ao contrario, poderia promover:

\footnotetext{
Consideradas como órgão mediador, as classes estão colocadas entre o governo em geral, por um lado, e o povo decomposto em esferas particulares e em indivíduos. Esta posição tem o significado de uma mediação comum ao poder governativo, a fim de que o poder soberano não pareça isolado como um extremo, e, portanto, uma simples autoridade soberana e um arbítrio, a fim de que os interesses particulares das comunidades, corporações e indivíduos não estejam isolados e nem, principalmente, que os indivíduos cheguem a representar uma multidão e uma massa, antes se mantendo como expressão inorgânica do pensamento e da vontade e como simples poder compacto frente ao Estado orgânico (HEGEL, 1821 apud MARX, 1843, p. 103).
}

\begin{tabular}{|c|c|c|c|c|}
\hline Qevista Qialectus & Ano 2 & n. 3 & Julho-Dezembro 2013 & p. $84-102$ \\
\hline
\end{tabular}


Assim, foi partindo da apreensão de que os conflitos de interesses entre os homens giravam essencialmente em torno da questão da propriedade privada que Hegel desenvolvera em seus Princípios da Filosofia do Direito mediações que subssumissem tais conflitos numa Monarquia Constitucional. A mais relevante crítica a tais Princípios, a Crítica à Filosofia do Direito de Hegel de Karl Marx, parte desse ponto como fundamental.

Para Marx, Hegel perseguira um objetivo notável: sobrepor a racionalidade pública à racionalidade privada, negar a propriedade privada livre como racionalidade efetiva. Ocorre, entretanto, que ele se mantivera nos termos da própria propriedade privada ao tentar desenvolver uma razão efetivamente pública no interior de uma da forma pública alienada. Marx indica que a solução de Hegel se fundamenta numa irrevogabilidade da cisão de interesses particulares e comunitários que só se resolve na sobreposição de um interesse particular sob forma de interesse geral: Estado. Assim, sendo o Estado um interesse particular que confina os conflitos porque surge como interesse geral, o Estado mais lógico é o corporificado num indivíduo que já é soberano sobre os demais indivíduos no desde o nascimento. Mas esta soberania só se realiza através de mediações. O interesse geral em Hegel só se realiza como interesse idealmente derivado dos cidadãos, ou seja, se auto-alienando como Espírito Finito nos homens dispersos e retornando a si mediando-se através da integração dos interesses particulares (finitos) em classes sociais e destas dos poderes executivo e legislativo.

Todas as categorias que Hegel desenvolvera como mediações para unidade se revelaram justamente o desenvolvimento da oposição entre o interesse particular e o interesse geral tal como se fosse uma oposição entre extremos reais. Para Marx, não eram mediações reais e sim ilusórias: entre extremos reais não pode haver mediação precisamente porque se trata de
extremos reais. Por outro lado, também não necessitam de mediação alguma,
pois são de natureza contrária. Nada têm em comum, não se reclamam nem se
complementam mutuamente (...) Devemos notar que tanto o polo norte como o
sul são, ambos, polos; seu ser é idêntico. (...) O norte e o sul são determinações
opostas de uma mesma entidade. São aquilo que são apenas como
determinação diferente e enquanto essa determinação diferente. Os extremos
verdadeiros e reais seriam polo e não-polo (...) Aqui a diferença seria uma
diferença existencial; ali uma diferença de seres, de dois seres (MARX, 1843,
p. 136).

\begin{tabular}{|l|l|l|l|l|}
\hline Qepista Dialectus & Ano 2 & n. 3 & Julho-Dezembro 2013 & p. 84-102 \\
\hline
\end{tabular}


Sendo o Estado uma forma em si, as mediações hegelianas são antes um extremo concreto a não relativo. Marx promove aqui uma crítica de cunho feuerbachiano ${ }^{7}$ : em Hegel, a existência da multidão é uma obra da Ideia em si ao invés da Ideia em si ser obra da multidão. Enquanto "o Estado surge da multidão tal como esta existe enquanto membros da família e da sociedade civil; a especulação anuncia este acontecimento como uma realização da Ideia, não da Ideia da multidão, mas sim de uma Ideia subjetiva diferente dessa mesma" (MARX, 1843, p. 136). Ao tratar o Estado alienado como um Estado de fato fundamentado em um elemento indeterminado, Hegel desenvolvera a oposição entre interesse geral e interesse particular como uma existência ontológica: a ideia pura distinta das ideias populares, concretamente determinadas, é a racionalidade real e absoluta sobre as demais.

Para Marx, não existe tal oposição ontológica: os opostos são uma mesma determinação que, pela alienação, supõem-se extremos reais, cindidos e opostos. O ser efetivo estaria em um dos extremos e o outro extremo seria uma ontologia completamente ilusória e projetada pelo primeiro. $\mathrm{Na}$ oposição enquanto determinações opostas "mesmo quando os extremos se apresentam verdadeiramente reais na sua existência, simultaneamente como extremos, é somente no interior do ser de um deles que se encontra a determinação de ser um extremo" (MARX, 1843, p. 137). Com efeito, no caso de extremos como determinações opostas no interior de uma mesma existência, trata-se de extremos que só se dão um em relação ao outro no interior de uma determinação - e não de uma indeterminação. A unidade e é assim a retomada do extremo real de sua determinação lançada por ele mesmo ao outro extremo. O extremo seria o verdadeiro ser que se autoprojetou num outro extremo alienado e oposto a si não é nem o extremo sociedade civil nem o extremo Estado, mas é a Ideia pura, um extremo indeterminado dado num além dos fenômenos.

Não admitindo o ser/princípio que se aliena como determinado, a razão hegeliana permanecia no interior na tradição teológica: a unidade efetiva é a razão alienada entendida como mera Ideia em si, Mas, desta maneira, os interesses dos homens permanecem cindidos entre interesse geral e interesse particular através da

\footnotetext{
7 "Na filosofia (hegeliana) o princípio tem um sentido particular, tal como requer a ciência filosófica: o significado de um primeiro princípio em si mesmo. Mas o que eu gostaria de questionar é: por que o princípio deve ser tomado neste sentido? A própria noção de princípio não está sujeita a crítica? É uma verdade imediata e universalmente válida? Por que eu não poderia abandonar no começo a noção de princípio e, então, voltar-me diretamente para aquilo que é real? Hegel começa do Ser, isto é, da noção do Ser ou do Ser abstrato. Por que eu não poderia começar do próprio ser em si mesmo, isto é, do Ser real?" (FEUERBACH, 1839, p. 205, tradução nossa.)
}

\begin{tabular}{|c|c|c|c|c|}
\hline Qevista Qialectus & Ano 2 & n. 3 & Julho-Dezembro 2013 & p. $84-102$ \\
\hline
\end{tabular}


oposição Estado e sociedade civil que só se resolvem num idealismo. Os extremos que deveriam ser mediados - interesse geral e interesse particular não se resolvem porque o Estado é desenvolvido como uma razão que é soberana por natureza e não por determinação do povo. As mediações formais seriam apenas um reconhecimento de tal soberania natural. Mas ao trazer a realização do Estado racional para um ato de nascimento natural que objetiva uma Razão Universal, Hegel acabara por desenvolver o Estado como natureza universal e não como um universal determinado pelos homens:

\footnotetext{
Hegel julga ter demonstrado que a subjetividade do Estado, a soberania, o monarca, é 'essencial', 'determinada' como tal indivíduo e desprovida de qualquer outro conteúdo; e na medida em que é esse indivíduo, é determinada de uma maneira natural imediata pelo seu nascimento natural. (...) No cume do Estado não estaria a razão, mas sim a natureza (MARX, 1843, p. 80).
}

Assim, o Estado de Hegel é a forma através da qual a essência da natureza determina a si um ordenamento universal, de modo que este é natural. "A soberania inerente ao monarca é considerada aqui de um ponto de vista formalmente místico, assim como os teólogos encontram o Deus pessoal na natureza” (Ibidem). O Estado político em Hegel não é meio dos homens determinarem uma racionalidade social revogável e sim meio da natureza determinar sua própria ordem, de modo que essa determinação é uma espécie de reconhecimento da natureza sobre sua própria ordem absoluta. Mas, critica Marx, Hegel não explicara em nenhum momento porque é que a constituição racional do organismo universal seria a constituição política e não outro sistema qualquer:

\begin{abstract}
O que autoriza [Hegel] a escrever "Este organismo é a constituição política"? Porque não dizer: "Este organismo é o sistema solar"? Somente pelo fato de Hegel ter determinado imediatamente "as diversas facetas do Estado"como "diversos poderes" (...) A consequência para que verdadeiramente tende é a determinação do organismo como constituição política; mas não existe nenhuma ponte que permita passar da ideia genérica do organismo para a ideia determinada do organismo do Estado ou da constituição política e nunca será possível construir semelhante ponte (MARX, 1843, p. 26).
\end{abstract}

$\mathrm{Na}$ verdade, não existia nenhuma ponte objetiva entre a constituição de leis políticas e a constituição de leis universais, tal como Hegel pretendia. A crítica à Filosofia do Direito de Hegel insere-se assim num projeto de crítica do voo de uma racionalidade particular a uma universalidade abstrata. Os Princípios da Filosofia do Direito de Hegel apenas expressariam de modo mais explícito o misticismo de sua lógica. No seu elemento constituinte indeterminado, Hegel revelou que mantivera uma razão em si pressuposta à determinação humana atuando por trás como fundamento da

\begin{tabular}{|l|l|l|l|l|}
\hline Qevista Dialectus & Ano 2 & n. 3 & Julho-Dezembro 2013 & p. 84-102 \\
\hline
\end{tabular}


realidade efetiva. Nele o real é objetivo e concreto apenas enquanto conteúdo da Ideia, sendo esta, portanto, o fundamento e finalidade de si mesma:

O real chega a ser fenomênico, mas a Ideia só tem como conteúdo esse fenômeno. Por outro lado, a Ideia tem apenas uma finalidade lógica: "tornar-se um espírito real infinito para si”. Neste parágrafo é formulado todo o mistério da filosofia do direito e da filosofia hegeliana em geral (MARX, 1843, p. 14).

Marx indica o parágrafo 262 Princípios da Filosofia do Direito como a revelação mais explícita da queda de Hegel num idealismo unilateral. Trata-se do parágrafo no qual os indivíduos concretos da multidão são afirmados como mera expressão do espírito num modo finito, mediatizado pela família e sociedade civil:

\begin{abstract}
A ideia real, o Espírito que se divide a si próprio nas duas esferas ideais do seu conceito, a família e a sociedade civil, consideradas como sua finitude, para emergir da sua idealidade como espírito real infinito para si, atribui portanto a essas esferas a matéria desta sua realidade finita, a saber, os indivíduos enquanto multidão e fá-lo de tal modo que no indivíduo esta atribuição surge mediatizada pelas circunstâncias, pelo arbítrio e pela própria escolha do seu destino (HEGEL, 1821, apud MARX, 1843, p. 10).
\end{abstract}

Assim, foi ao dar os indivíduos no modo família e sociedade civil como mera mediação para o surgimento do Estado como racionalidade absoluta/fim do espírito que Hegel acabara por revelar o concreto e objetivo como mediação da Razão ao invés da Razão como mediação do concreto consigo mesmo. Em Hegel o Estado é simplesmente a consciência posta da razão humana anteriormente inconsciente, mas é a consciência posta de uma razão em si que apenas se mediatizou nos seres humanos Ao contrário de considerar a razão um interesse geral dos indivíduos que se desenvolve mediados pela família e pela sociedade civil e Estado, Hegel considerara o interesse geral como Estado pressuposto que se desenvolve em indivíduos, família, sociedade civil e Estado posto (Estado em si), sendo o Estado não uma ordem política e sim uma ordem da natureza universal:

a família e a sociedade civil são concebidas como esferas ideais do
Estado,como as esferas da sua finitude (...) A relação real é "que no indivíduo
esta atribuição surge mediatizada pelas circunstâncias, pelo arbítrio e pela
própria escolha do seu destino". [Mas] este fato, essa relação real, é anunciada
pela especulação como uma manifestação, como um fenômeno. Essas
circunstâncias, esse arbítrio, essa escolha do seu destino, essa mediação real
constituem precisamente o fenômeno de uma mediação que a ideia real
executa sobre si mesma e que se desenvolve nos bastidores. (...) A família e a
sociedade civil erigem-se a si mesmas em Estado. Constituem o elemento
atuante. De acordo com Hegel são, ao contrário, atuadas pela ideia real
(MARX, 1843, p. 11).

A Ideia real não seria uma derivação dos interesses individuais da família e da sociedade civil, mas sim um princípio em si mesma que só passa pela família e pela sociedade civil para retornar a si mesma. Para Marx (1843, p. 11), Hegel identifica que

\begin{tabular}{|l|l|l|l|l|}
\hline Qexista Dialectus & Ano 2 & n. 3 & Julho-Dezembro 2013 & p. 84-102 \\
\hline
\end{tabular}


“o Estado não pode existir sem a base natural da família e a base artificial da sociedade civil", mas ao invés de dar esta condição como princípio do Estado, "esta condição é formulada como sendo o condicionado, o determinante como sendo o determinado (...) a ideia só se rebaixa à 'finitude' da família e da sociedade civil para dar origem, através da sua supressão, à sua infinitude em si” (Ibidem).

Assim, a pretensa dialética que faria uma identificação entre particular e universal passando ambos termos um pelo outro se revela na filosofia política hegeliana um processo de sujeição unilateral: os opostos subjetivo/objetivo não se tocam, não se entrelaçam de fato, dado o pressuposto inconsciente de intransponibilidade concreta da propriedade privada, Hegel se contentou com uma possibilidade de transponibilidade formal da propriedade privada, contentamento próprio de sua filosofia que elevou a forma alienada à uma universalidade efetiva, emperrando uma dialética idealistaobjetiva efetiva ao se fechar no plano idealista como plano em si.

Marx (1843, p. 103) aponta uma contradição de Hegel consigo mesmo: "O próprio Hegel afirma que a possibilidade de acordo é a 'possibilidade da oposição"”, mas "é obrigado a constituir um elemento que seja a 'impossibilidade da oposição' e a 'realidade do acordo"'. Hegel buscou o elemento constituinte no poder legislativo justamente em nome de uma realidade do acordo, a unidade indeterminada. Entretanto, tal elemento, sendo identidade com o embrião da propriedade como sujeito, é justamente a separação

Hegel faz do elemento constituinte a expressão da separação; mas este elemento deve ser simultaneamente representante da identidade que não existe. Hegel conhece a separação existente entre sociedade civil e Estado político, mas quer expressá-la como unidade no interior do Estado. (...) O ponto realmente importante é o de Hegel ver uma contradição na separação da sociedade civil e da sociedade política. E o seu erro está em contentar-se com a aparência desta solução e em dá-la como tal (...) de fato, o elemento político constituinte a que Hegel se refere não é mais do que a aceitação efetiva da relação real existente entre o Estado e a sociedade civil (MARX, 1843, p. ??).

A constituição constituinte fora defendida pelo Hegel por este entender a oposição como natural e entender que a única unidade possível era um Estado no qual esta oposição não fosse reconhecida (a não ser na consciência do Estado em si: monarca). Daí a unidade formal ter sido afirmada como unidade absoluta.

A inversão de Hegel entre sujeito e predicado outrora indicada por Feuerbach é revelada aqui como promovida especificamente no desenvolvimento do Estado político racional. Ao identificar que o Espírito posto é o Estado político em si, Hegel revelara também que o seu espírito pressuposto é, na verdade, o Estado pressuposto. Se o Estado

\begin{tabular}{|l|l|l|l|l|}
\hline Qepista Dialectus & Ano 2 & n. 3 & Julho-Dezembro 2013 & p. 84-102 \\
\hline
\end{tabular}


político em si é a Razão em sua forma consciente, então a forma da Razão pressuposta é o fundamento do Estado: o fim revela o princípio. Em Hegel, o Estado político em si de modo mais absoluto é o Estado mais consciente de seu fundamento particular irrevogável: o interesse de propriedade particular. Para além de Feuerbach, Marx apreendera que a inversão de Hegel deriva do elemento indeterminado do Estado hegeliano ser também um elemento indeterminado da ordem natural universal e de tal elemento ser o interesse de propriedade privada - ainda que Hegel de fato acreditasse que a propriedade privada agrária se contrapusesse à propriedade privada livre e fosse, por isso mesmo, equivalente a uma razão pública em si.

Hegel acertou em sua identificação de que no capitalismo a liberdade individual surgira como mero individualismo, liberdade competitiva, e que era necessário ultrapassar essa competição individual destrutiva da sociedade civil com o desenvolvimento da sobreposição do interesse comum. O seu erro foi considerar que para a sobreposição do interesse geral seria suficiente a fixação de uma forma de Estado contraposta ao próprio conteúdo fundamento do Estado.

Para Marx, não se trata de um desvio moral: Hegel tinha uma convicta oposição à da propriedade privada completamente livre. Trata-se, antes, de uma ilusão do filósofo de que a pura resolução formalista pode reverter um conflito de conteúdo. Na verdade, Hegel teria contribuído não com uma resolução efetiva do conflito moderno, mas por expor de modo profundo a ilusão do Estado moderno sobre si mesmo: o Estado é o interesse da propriedade privada afirmada ficticiamente, formalmente como interesse público e que por conta dessa mera formalidade pensa-se público de fato. A ilusão do Estado é a de não ser determinado efetivamente pela propriedade privada, seu fundamento, seu princípio: “Qual é o poder do Estado político sobre a propriedade privada? O próprio poder da propriedade privada, o seu ser conduzido à existência. Que resta ao Estado político em oposição a este ser? A ilusão de determinar exatamente onde ele próprio é determinado." (MARX, 1843, p. 103). A identificação da alienação completa da forma como resultado do desenvolvimento de uma cisão natural numa forma mais consciente promovida por Hegel é uma aceitação da alienação moderna:

O ponto realmente importante é o de Hegel ver uma contradição na separação da sociedade civil e da sociedade política. E o seu erro está em contentar-se com a aparência desta solução e em dá-la como tal (...) de fato, o elemento político constituinte a que Hegel se refere não é mais do que a aceitação efetiva da relação real existente entre o Estado e a sociedade civil (MARX, 1843, p. 116). 
A aceitação da relação moderna de alienação do interesse geral no mero formalismo do Estado político em si é a busca de uma solução no interior da forma alienada ao invés de uma tentativa de dissolução da forma alienada. Para Marx, a proposta hegeliana de subsumir as oposições numa unidade revelou-se na pratica como uma sobreposição de unidade ilusória derivada do pressuposto de uma oposição irrevogável.

Embora afirme ter desenvolvido uma razão absoluta que abraça a divisão, Hegel na verdade buscou uma razão que não reconhece a divisão. Ao "não fazer surgir a sociedade civil como algo que se constitui a si mesmo em elemento legislativo nem como massa compacta ou multidão decomposta em átomos; [Hegel] não quer nenhuma separação entre a vida civil e a vida política" (MARX, 1843a, pp. 114-116). Ocorre que, não reconhecendo que a separação entre a vida civil e a vida política não é meramente conceitual, ele acabara por impor uma intransponibilidade da cisão no plano efetivo que nada mais é que um pressuposto (inconsciente) de uma intransponibilidade da propriedade privada.

$\mathrm{Na}$ verdade, através da crítica de Marx expressa-se que aquilo que Hegel chamou de ingenuidade infantil perdida para sempre é apenas a separação dos homens pela propriedade privada. É justamente tal separação que ele acabara por dar como irrevogável para sempre. Hegel negou a constituição representativa porque eternizou o interesse egoísta e a oposição interesse particular e interesse geral. Mas eternizou tal oposição porque, na verdade, eternizou a propriedade privada.

Contra Hegel, Marx (1843, p. 114) afirma que a propriedade privada não é um direito natural, mas um fato - a posse - desenvolvido como direito apenas juridicamente “a verdadeira razão da propriedade privada, a possessão, é um fato, um fato inexplicável, não é um direito. É somente através de determinações jurídicas que a sociedade dá à possessão de fato, que adquire a qualidade de possessão de direito, o caráter de propriedade privada". Ou seja, ainda que o desenvolvimento da posse fosse um fato inexplicável, isso não implicava que fosse um desenvolvimento natural. Desmistificar o domínio social da propriedade privada estará no centro da posterior crítica de Marx à economia política. Mas já no Marx republicano tal crítica surge embrionária: a propriedade privada não existe por natureza, a posse é desenvolvida socialmente e afirmada como lei pelos próprios homens. Mais especificamente, afirmada como lei pela menor parte dos homens. É por conta do fato propriedade

\begin{tabular}{|l|l|l|l|l|}
\hline Qepista 2 ialectus & Ano 2 & n. 3 & Julho-Dezembro 2013 & p. 84-102 \\
\hline
\end{tabular}


privada não ser real para a maioria que a democracia arrastaria o seu desaparecimento como interesse público, dominante e fundamental.

Para Marx, a solução meramente formal seria a racionalidade absoluta apenas se o interesse egoísta fosse intransponível. Entretanto,no bojo da compreensão de que toda racionalidade é racionalidade determinada, a cisão entre interesse geral e interesse particular não se trataria de uma cisão natural e ontológica e sim de uma alienação socialmente engendrada. Na contramão de Hegel, Marx defende que é preciso, antes e sobretudo, desalienar o Estado político e que desalienar o Estado político é desenvolvelo como racionalidade determinada democraticamente. Sua compreensão de democracia se expressa num sentido não liberal: trata-se da negação da razão particular sob forma pública e afirmação da racionalidade pública como aquela que é mais amplamente e efetivamente determinada pelo povo e representante do interesse do povo.

A constituição representativa democrática seria um progresso ao Estado moderno em relação à constituição constituinte, monárquica, justamente por ser um caminho para dissolver a forma como universalidade autoconstituinte, como um universal em si e para si, e revela-la como uma universalidade particular constituída. É assim que Marx sugere o caminho para a dissolução da oposição é reconhecimento da oposição moderna como uma oposição não ontológica. Se "[Hegel] não quer [reconhecer] nenhuma separação entre a vida civil e a vida política” (MARX, 1843, p. 114- 116), Marx, por outro lado, quer

\begin{tabular}{|c|c|c|c|c|}
\hline Qevista Qialectus & Ano 2 & n. 3 & Julho-Dezembro 2013 & p. $84-102$ \\
\hline
\end{tabular}


a democracia justamente para expor a forma separada e em si como predicado e não como sujeito. A democracia deve impedir que a forma seja tomada como um céu, ou seja, impedir que a forma seja entendida como uma racionalidade que se autoconstitui e à qual os homens devem se submeter cegamente. A constituição representativa democrática faria o interesse geral surgir não como forma alienada, não como universal em si, mas sim como forma determinada. É este o sentido em que Marx fala de democracia como desaparecimento do Estado:

\begin{abstract}
Na monarquia, a constituição política, que é um aspecto particular, tem o sentido do universal que domina e determina todo o particular. Na democracia, o Estado, enquanto particular, é somente particular; enquanto universal, constitui o universal real, isto é, algo determinado que se diferencia do outro conteúdo. Os franceses modernos interpretam isso afirmando que o Estado político desaparece na verdadeira democracia, o que está correto no sentido de que, enquanto Estado político, enquanto constituição, já não vale para totalidade (MARX, 1843, p. 48).
\end{abstract}

Marx indica sua perspectiva de democracia relacionada com as perspectiva dos franceses. Trata-se aqui de um flerte do republicano com os socialistas e comunistas que indicavam o comunismo como a verdadeira democracia ${ }^{8}$. Na democracia a constituição política não é uma constituição de uma razão universal e absoluta e sim de uma razão específica que pode ser, portanto, revogável por uma outra razão. A constituição surge como determinada pelos homens e não mais como um Estado em si. Trata-se da dissolução do Estado indeterminado, dissolução do Estado político como uma razão pública em si e desenvolvimento do Estado político determinado, como razão pública derivada dos homens. Dissolver o Estado é dissolver a razão enquanto sujeito princípio e independente dos homens, enquanto formalidade por si, indeterminada, universal e absoluta sobre os homens. "Na democracia, a constituição, a lei e o próprio Estado são apenas uma autodeterminação do povo, um determinado conteúdo do povo. (...) Na democracia o Estado abstrato deixou de ser o elemento dominante" (MARX, 1843, p.48). Com o desenvolvimento da democracia a vida civil, dominada pelo interesse de propriedade, deve tornar-se inessencial:

É apenas na eleição absoluta, tanto ativa quanto passiva, que a sociedade civil atinge realmente a abstração de si mesma, a existência política como sua

\footnotetext{
${ }^{8}$ Tal como afirma LOBÃO (2011, p. 40-41): “Ora, tudo indica que tais franceses modernos (neuren Franzosen - a rigor, franceses recentes ou novos franceses) são os reformadores sociais, socialistas e comunistas: no ano anterior, enquanto dirigia a Gazeta Renana, num artigo, em que participava de uma controvérsia a respeito do comunismo, menciona a esse respeito tão somente os franceses, seus contemporâneos, Fourier, Leroux, Consideránt e Proudhon; enquanto escrevia esses manuscritos, numa carta a Ruge colocara-se em interlocução com os reformadores sociais (sem se reportar a outras tendências políticas), dos quais as principais referências são franceses, os socialistas Fourier e Proudhon e os comunistas Cabet e Dézamy (...) Cabet concebia o comunismo como a realização completa da democracia".
}

\begin{tabular}{|c|c|c|c|c|}
\hline Qenista Qialectus & Ano 2 & n. 3 & Julho-Dezembro 2013 & p. $84-102$ \\
\hline
\end{tabular}


existência essencial verdadeira e genérica. Mas esta abstração, ao ser completamente elaborada, suprime-se. Pelo fato de a sociedade civil ter realmente formulado a sua existência política como sua existência verdadeira, é simultaneamente obrigada a considerar sua existência civil, em oposição à sua existência política,como inessencial. E o desaparecimento de uma dessas partes separadas arrasta o desaparecimento da outra, sua contrária. Portanto, a reforma eleitoral constitui, no interior do Estado político abstrato, o pedido da sua dissolução e o da dissolução da sociedade civil (MARX, 1843, p. 185).

Marx considera naquele momento que para revogar a propriedade privada como fundamento indeterminado do interesse geral é preciso desenvolver o interesse geral como interesse determinado pela maioria dos homens num sufrágio universal. A partir da crítica mais profunda de Hegel Marx não poderia continuar a buscar a mera alteração da forma alienada do Estado político (de Monarquia Absolutista para República Democrática) como realização da emancipação humana. A libertação dos homens não se realizaria na mera passagem da Monarquia Absolutista à República Democrática, mas na resolução do problema da propriedade privada. Fica bastante claro que o sufrágio universal deveria levar ao desaparecimento do Estado político alienado no sentido de desaparecimento da sociedade que alienou seu ordenamento social na propriedade privada. Aqui, formular a existência política como existência essencial é ter a vida comunitária e não a vida privada como existência particular essencial.

Em contraposição a um interesse geral como racionalidade universal que se autodetermina numa constituição constituinte, ou seja, ao interesse geral como Estado político em si, Marx defenderá o interesse geral como racionalidade determinada numa constituição representativa do povo e chama tal constituição popular da racionalidade social de dissolução do Estado político. Sendo Estado político o mesmo que interesse geral indeterminado pelo povo e determinado pelo interesse de propriedade, o interesse geral determinado pelo povo é, simultaneamente, a dissolução do Estado político, ou seja, a dissolução do interesse de propriedade como interesse geral.

\section{Referências}

ARANTES, Paulo Eduardo. Hegel: Vida e Obra. São Paulo: Editora Nova Cultural, 2005 .

DESAI, Meghnad. A vingança de Marx: a ressurgência do capitalismo e a morte do socialismo estatal. Tradução de Sérgio Bath. São Paulo: Codéx, 2003.

\begin{tabular}{|l|l|l|l|l|}
\hline Qepista 2 ialectus & Ano 2 & n. 3 & Julho-Dezembro 2013 & p. 84-102 \\
\hline
\end{tabular}


FEUERBACH, L. (1839) Towards a Critique of Hegel's Philosophy. In Fiery Brook: Selected Writings of Feuerbach. Translated by Zawar Hanfi, New York: Doubleday, 1972.

HEGEL, G.W.F. Filosofia da História. Tradução de Maria Rodrigues e Hans Harden.

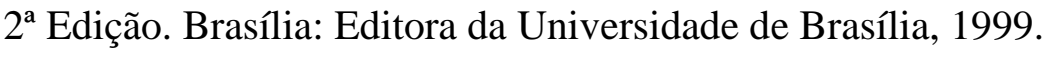

. (1821) Princípios da Filosofia do Direito. São Paulo: Martins Fontes, 2003.

LOBÃO, Evandro de Carvalho. Teoria da Revolução e Formação Política no Jovem Marx. Tese de Doutorado. São Paulo, USP, Faculdade de Educação, 2011.

MARX, Karl. (1843) Crítica da Filosofia do Direito de Hegel. Tradução de Conceição Jardim e Eduardo Lúcio Nogueira. Lisboa: Presença, 1983. 